\title{
Standing rock and the Indigenous commons
}

\section{Dorothy Kidd}

To cite this article: Dorothy Kidd (2020): Standing rock and the Indigenous commons, Popular Communication

To link to this article: https://doi.org/10.1080/15405702.2020.1781862

$$
\text { Published online: } 03 \text { Jul } 2020 .
$$

Submit your article to this journal ¿

\section{Q View related articles $₫$}

View Crossmark data [ 


\section{Standing rock and the Indigenous commons}

\section{Dorothy Kidd}

\begin{abstract}
A new cycle of communications commons has become part of the contemporary repertoire of Indigenous first nations in North America. The mobilization of the Standing Rock Sioux is perhaps the bestknown example of a continent-wide cycle of resistance in which Indigenous communities have employed a combination of collectively governed land-based encampments and sophisticated trans-media assemblages to challenge the further enclosure of their territories by the state and fossil fuel industries and instead represent their political and media sovereignty, and prefigure a more reciprocal relationship with other humans and with nature. Although their practices of commoning resemble other radical commons projects, the contemporary Indigenous commons begs for a reassessment of the critical framework of the commons. In this article, I discuss the critical commons literature and compare it with the practices of commoning in the antiextractivist encampments of Standing Rock.
\end{abstract}

\section{ARTICLE HISTORY}

Received 2 March 2020

Revised 13 May 2020

Accepted 27 May 2020

\section{KEYWORDS}

Commons; communications commons; indigenous media; indigenous history; social movements; environmental justice; extractivism; extra-activism; anti-colonial; social media

\section{Introduction}

In April 2016, the Indigenous youth group ReZpect Our Water started a social media campaign to stop the proposed Dakota Access Oil Pipeline (DAPL), which was threatening to harm their water sources and sacred sites (thus the hashtags \#StandingRock, \#NoDAPL, \#mniwiconi and \#waterislife). Soon after, Standing Rock Sioux historian LaDonna Brave Bull Allard, her grandchildren, and other women leaders set up the camp of the Sacred Stones on their traditional territory as a center for direct action, spiritual resistance, cultural preservation, and defense of Indigenous sovereignty. ${ }^{1}$ By the fall of 2016 , as many as 20,000 Indigenous and non-Indigenous supporters had joined them to form three collectively governed camps, with over 1.5 million people actively participating in hundreds of cyber spaces. Led by the Standing Rock Sioux, the land- and cyber-based encampments were supported by every single Native American tribe, hundreds of other Indigenous nations from across the Americas and northern Europe, U.S. Military veterans, and a very wide coalition of environmental and social justice movements.

The efforts to stop the construction of the Energy Transfer-owned pipeline were unsuccessful, as Donald Trump reinstated the project in his first week as U.S. President in January 2017. Soon after, on February 23, the remaining water protectors were forcibly evicted and the camps evacuated (Deem, 2019, p. 122). Nevertheless, \#StandingRock has been remarkable for several reasons relevant to this special issue. The mobilization captured more national and international media attention than any previous Indigenous movement in North America. Arguably they reached far more people with their own self-generated 
media that challenged neo-colonial stereotypes, and instead emphasized their long-standing environmental knowledge and opposition to their forced relocation by the extractive industries (Brígido-Corachán, 2017). Since then, the Standing Rock Sioux have lent their support to several Indigenous-led land-based struggles against extractivism, many of which have drawn on the Standing Rock media power and dubbed themselves 'the next Standing Rock" (Saunders, 2018; Wiles, 2017). ${ }^{2}$

The Standing Rock Sioux mobilization also begs for a reexamination of the communications commons, including my own previous work (Kidd, 1998, 2015). Certainly, the Standing Rock encampments resembled other contemporary political projects of radical transformation informed by the critical commons (Turner \& Brownhill, 2004; Linebaugh, 2008, 2010; Caffentzis \& Federici, 2014; de Angelis, 2014; Deleixhe, 2018; Federici, 2019; García López, Velicu, \& D’Alisa, 2017; Hollender, 2016; Singh, 2017; Velicu \& García-López, 2018). Their practices were similarly based on an ethos of caring, and collective social transformation (Estes, 2019), echoing the cardinal idea of commoning first articulated by Peter Linebaugh (2010) and more recently taken up by a number of other scholars (Federici, 2019; Kanngeiser \& Beuret, 2017). Paralleling the formations of the Occupy movement, which some commentators had described as a commons (Fortier, 2017, p. 8), and which in earlier work I had dubbed as a communications commons, the Standing Rock water protectors operated from land-based encampments, and articulated and circulated their struggle through a decentralized assemblage of all manner of collectively governed communications (Kidd, 2015).

Nevertheless, Standing Rock and the current movement of Indigenous land-based actions represent some significant differences. Indigenous activists had called out some of these differences during the Occupy movement. Dakota professor Waziyatawin and Nishnaaabeg writer John Paul Montano, among others, argued that that the Occupy camps were built on Indigenous land, and that if the Occupy movement wanted to further more radical democratic and egalitarian change, they needed to reckon with the long and violent history of colonial dispossession of Indigenous peoples and ways of life (Fortier, 2017; Montano, 2011; Waziyatawin, 2014).

Shortly after, Dene scholar Glen Coulthard (2014) wrote that "those inclined to advocate a blanket "return of the commons" as a redistributive counter strategy to the neoliberal state's new round of enclosures" must recognize that "the 'commons' in liberal settler states" belongs to somebody --the First Peoples of this land." Ignoring "the injustice of colonial dispossession" he argued, not only "risks becoming complicit in the very structures and processes of domination," but also overlooking "invaluable glimpses into the ethical practices and preconditions required for the construction of a more just and sustainable world order" as the Indigenous commons harbors "profound insights into relations within and between human beings and the natural world based on reciprocity, nonexploitation and respectful coexistence" (12).

Responding to these critical interventions, I am revisiting the communications commons at Standing Rock. This article has biographical, political and intellectual roots. Part of my family history follows the nineteenth century trajectory of white colonial settlers across what is now called Canada. I became even more aware of the unbroken link between Indigenous commons and colonial and contemporary practices of enclosure, and my own status as a white settler, when I worked for Indigenous communications groups in northern Canada in the 1980s and 1990s. Then in 2011, I listened as scholars Audra Simpson, Glenn 
Coulthard and Alfred Taiaiake spoke in Vancouver about Indigenous resurgence projects of art, scholarship and land-based practices for self-determination. Later in 2015, in a Jacobin magazine interview, Coulthard said that "Indigenous land-based direct action is positioned in a very crucial and important place for radical social change" "in settler-colonial political economies like Canada, which is still very much based on the extraction and exploitation of natural resources" (Epstein, 2015). ${ }^{3}$

I proceed in three moves. I first discuss Coulthard's concerns about Marxist commons theory and some of the revisions by critical commons theorists who have taken up Indigenous perspectives. Second, I briefly review the literature about Indigenous commons and the colonial-era enclosures in North America. I then draw the line forward to the Standing Rock Sioux mobilization, based primarily on the work of historian Nick Estes (2019) and Indigenous educator Dina Gilio-Whitaker (2019). Next I examine the commons-like formations at Standing Rock, looking especially at the relations among commoners and their practices of commoning; and finally I discuss the lessons for our understanding of the communications commons.

\section{The critical commons: a conversation}

Early in the introduction to Red Skin, White Masks (2014) Glen Coulthard recounted Marx's narrative of the horrendous violence of the European enclosures that dispossessed Indigenous peoples from their common territories, and set the stage for the capitalist mode of production. He argued that Marx's "critique of capitalist exploitation" and "the entangled relationship between capitalism and colonialism" is critically important for Indigenous understandings. He cited Tsimshian anthropologist Charles Menzies, who wrote that Marxism helps to understand the ways that "power is structured through ownership," and the state's role in the accumulation of capital and the redistribution of wealth from the many to the few (Menzies, 2010 in Coulthard, 2014, p. 8).

Putting Marx's thesis of the commons and enclosures into conversation with Indigenous critical thought and practices, Coulthard laid out what he considered the flaws in the argument. First, he challenged the temporal framing; rather than a one-time occurrence the enclosures are continuing everywhere, if with even greater state-orchestrated violence, as several contemporary commentators such as David Harvey, Sylvia Federici, Taiaiake, Alfred, Rauna Kuokannen and Andrea Smith have noted (Coulthard, 2014, p. 9). Second, Coulthard debunked the proposition that "primitive accumulation" constituted a necessary and inevitable process for all societies which only served to reinforce the ideas that nonEuropeans are "less-developed" and "absent of history" (2014, p. 10). Third, borrowing from Sylvia Federici, Coulthard proposed centering the colonized subject vis-à-vis the effects of dispossession, rather than the waged male proletariat (11).

Coulthard did not expand further on the commons in that volume. However, several non-Indigenous scholars have updated critical commons theory in light of the Indigenous commons (Federici, 2019; García López, Velicu and D'Alisa, 2017; Singh, 2017; Velicu \& García-López, 2018). Foremost among them is Sylvia Federici, who has written that the question of our relationship to the Native commons is an urgent political one $(2019, \mathrm{p} .81)$. Federici starts her recent text with an acknowledgment of the collective societal debt to the first commoners, the "Native American First Nations", who gifted much of their wealth, 
food and medicine, healing practices, and political institutions to all of us, and who continue to produce "new communal forms of social organization" (79).

Federici has long challenged the classical Marxist framework in which the European capitalist model of industrial production was a necessary stage for the liberation of humanity, with the primacy given to male industrial workers as the leading protagonists of human liberation from exploitation. In Re-Enchanting the World: Feminism and the Politics of the Commons (2019), she wrote that it is women who are "leading the struggle in defense of the commons," including at Standing Rock where they "built the infrastructure that enabled" the camp (82). Their collective assembly was part of a strategy for the "social relations we aim to achieve, "as well as the means for their construction, a perspective we bring to every struggle and movement in which we participate" (Federici, 185).

For Federici (2019), the critical commons constitutes an anti-capitalist political strategy (86). The motivating force of the current uptake of the commons by a variety of anticapitalist movements, she argues, is the profound crisis in which the state and the capitalist market provide less and less of the means of social reproduction, and instead have increased both impoverishment and militarization (183). Drawing from experiences of grassroots women's groups throughout the world, Federici argues that "commoning the material means of reproduction," can undermine the hold that capitalism has on our lives by producing a new collective identity, a counter power that is "the first line of resistance" and the "condition for the construction of autonomous spaces"(108).

Nevertheless she cautioned that many commons efforts have either been co-opted by the state, circumscribed within the capitalist market, or narrowly limited by the imposition of new gates that may even deepen "racial and inter-class divisions" (89).

Many of the critical commons theorists build on the concept of commoning, introduced by Peter Linebaugh, who wrote that collective processes of commoning are always embedded in a specific ecology and involve particular labor processes (2008, p. 45). In a conceptualization that parallels North American Indigenous practice, he argued that commoning is always more-than-human, involving people, plants, animals, resources and objects (2008, p. 45). Writing about Indigenous commons in India, Singh underscored the "sense of being-incommon" with their ecologies and other "members of the human community" (2017, p. 765). For Singh, much like Federici, "commoning is a way to reclaim control over our lives and the condition of our reproduction "(766); and a place where "new subjectivities and social relations emerge through affective relations and immersion in one's total biophysical environment (760). This emphasis on the fluid and not-taken-for-granted dimension of commons is central to most contemporary critical commons accounts. As Velicu and García-López suggest, the process of building commons not only interrupts the "dominant "capitalocentric imaginary" but activates "new senses of self." Nevertheless, they suggest that commoning does not necessarily result in an "alternative' commoner but instead comprises a range of contradictions and fluid ways of being, identities, and interests (2018, p. 6).

\section{Colonial-era indigenous commons}

The historical record of Indigenous commons-based societies in North America is still to be fully written, as are the multiple narratives of resistance to the successive enclosures of European colonial forces, the U.S. and Canadian nation states, and the incursion of white settlers. There were a vast plurality of commons, embodying many different systems of 
production and social reproduction, social norms and institutions, governance and communications (Hardison, 2006). Each had very specific and distinctive geographies produced in and productive of a particular place (Blomley, 2008, p. 320). For the most part, they operated with practices distinct from the European system of land as privately owned commodity, whose exchange value outweighed its use. Instead, most Indigenous nations did not "make property/non-property distinctions and so the very concept of the "public domain," invoked by open source activists and those espousing land-based and virtual commons is alien (Hardison, 2006, p. 3).

Although the pre-colonial Indigenous territories are no longer intact, much of the knowledge of their ecologies, and complex systems of collective "guardianship," "custodianship" and/or "stewardship" continue to be practiced. Communications were and continue to be key to these processes. Complex protocols govern what, who, when and how procedures were and are exercised (Hardison, 206). Distinct from contemporary free and open source practices that operate in some contemporary digitally based commons, as Hardison reminds us, the protocols came with clear social restrictions and expectations of obligations from people within the communities and with outsiders (3). As we will see in the commoning at Standing Rock, many communities developed complex rituals, words or ceremonial practices to accompany the protocols and record them for posterity.

\section{Extractivism is in the settler DNA}

Extractivism, or the massive exploitation of natural resources (such as gold, silver, minerals, lumber, gas and oil) was part and parcel of the colonial enclosures of the Indigenous commons and the murder and violent displacement of Indigenous peoples. The governments of both U.S. and Canada provided the military force, and financed and implemented tax incentives for the transportation and telecommunications infrastructure to export the raw commodities to Europe and then establish domestic industrial centers. In the U.S. the Doctrine of Discovery entrenched the legal groundwork after the fact for the dispossession of Indigenous peoples and the hyper-exploitation of the natural world (Gilio-Whitaker, 2019, pp. 56-57). The two nation states of the U.S. and Canada then enacted similar legal regimes that transformed communally stewarded territories into individual privately held plots of land (Rueck, 2014, p. 353).

Many Indigenous communities employed multiple strategies for resisting and surviving the forces of enclosure as part of the defense of their "collective and life-centered projects of subsistence commoning" (Turner \& Brownhill, 2004). Some, including among the Sioux, took up arms, while others signed treaties in the hopes of ensuring peace and rights to land, foodstuffs, healthcare and education (Estes, 2019). Throughout the continent, hundreds of communities refused to cede their customs, beliefs, languages, knowledges and communication systems even if they often had to take them underground to avoid repression. Many refused to accept the settler logic in which the environment was considered a resource to be exploited, rather than a commons to be protected, nurtured, stewarded, and nourished through practices of care (Singh, 2017).

\section{The new enclosures}

In Our History is the Future: Standing Rock versus the Dakota Access Pipeline, and the long tradition of Indigenous Resistance, Nick Estes (2019) drew a direct line between the struggles 
of the Sioux over dispossession and enclosure in the 19th century and the encampments of \#NoDAPL. Many of the historic leaders and key points in the struggles that he depicts were commemorated in the names, rituals and prayers of the Standing Rock encampments, as we will see below.

The Standing Rock Sioux are Lakota/Teton people, part of the Oceti Sakowin (literally seven Council Fires) whose territorial commons once spanned hundreds of miles from the western shores of Lake Superior to the Bighorn Mountains in Montana (Estes, 2019, p. 3); and who today number 100,000 to 160,000 people in the U.S. and Canada (Walker \& Walter, 2018, pp. 401-402). The Oceti Sakowin consistently asserted their political sovereignty and customary ways of living within their territories, despite continuing cycles of dispossession and enclosure. They faced off against the combined onslaughts of the U.S. Military and the white settlers from the gold, logging, cattle, and uranium extraction industries; and the massacre of the buffalo on which they depended (Estes, 2019; GilioWhitaker, 2019; Walker \& Walter, 2018). Then, in 1851 and again in 1868, they negotiated temporary reprieves from the violence with the signing of the two Fort Laramie Treaties (Estes, 2016); which notably included the land they were to re-occupy during \#DAPL (Lennard, 2017).

In the last decades of the 19th century, the U.S. state changed tactics. In 1887, the U.S. Government further fragmented the Oceti Sakowin territory into private property (often 160 acre parcels), and attempted to force Indigenous people to adopt settler farming practices via what was called the Sioux Bill (Whyte, 2017, p. 162). Then, in 1889, Congress further subdivided the remaining Sioux territories into six, one of which was the Standing Rock reservation (Whyte, 2017, 162; Brígido-Corachán, 2017, p. 72).

Throughout the 20th century, the Sioux continued to resist each new regime of enclosure. The privatization and control of the water and hydrological flows for the benefit of settler industry and agriculture dominate the narrative in the first half of the century (Whyte, 2017, p. 165). Between 1907 and 1934 millions of acres of the remaining Great Sioux Reservation were lost (Estes, 2016); and even more people were dislocated as their timber, grazing and agricultural lands were flooded for dams and irrigation systems (Estes, 2019 , pp. 10-12). In the last half of the twentieth century, oil and natural gas exploitation features more prominently.

Indigenous resistance to oil pipelines in North America dates back at least to the battle in 1968 against the Trans-Alaska pipeline (Gilio-Whitaker, 2019, p. 2), and then in the 1970s by the Dene, Inuit and Métis downstream in the MacKenzie Valley in Canada (Kidd, 2019). Then during the 1980s, oil and natural gas fracking around the world began to be promoted by the International Monetary Fund and World Bank as part of the Washington neo-liberal consensus; national governments were strongly encouraged to adopt corporate friendly laws and taxation policies for extractivist companies, and to deregulate their environmental and labor laws with the argument that potential profits could provide employment, tax revenue, trickle down wealth, and spill-on effects for local and national economies (Kidd, 2016).

The renewed exploitation of oil and natural gas was stepped up on both sides of the U.S. - Canada border at the turn of the millennium. On the U.S. side, the plan was for the dirty oil from the Bakken shale to be transported more than a thousand miles across four U.S. states via DAPL and other pipelines. On the Canadian side, pipelines carrying the Alberta tar sands oil would criss-cross the country and wind south to refineries in the U.S. 
Oil and natural gas pipelines are particularly vulnerable to contention as they stretch very long distances, and engage a long chain of people through rural and urban, Indigenous and non-Indigenous communities. What neither the two governments nor the fossil fuel industry didn't count on was the slow but steadily growing movement among front-line communities and their supporters against the pipelines and the larger ideology of extractivism (Kidd, 2016; Klein, 2014). In the last decade, communities within the larger Oceti Sakowin first mobilized against the Keystone XL and then the Dakota Access Pipeline (Estes, 2019; Gilio-Whitaker, 2019). Many of the campaigns, from the Micmac and Elsipogtog on the Atlantic side, to the Ojibwe in Northern Minnesota, and the Wet'suwet'en camps on the pipeline routes to the Pacific coast, have been based in landbased struggles in which Indigenous communities have established camps on their own land from which to oppose the pipelines.

\section{The commons at standing rock}

In April 2016, thirty young people from Standing Rock set up the ReZpect Our Water social media campaign to challenge the proposed Dakota Access pipeline (Petronzio, 2016). Tribal historian LaDonna Brave Bull Allard was also concerned that the pipeline would poison their drinking water, harm their fishing and agriculture, and damage their cultural and religious sites. Inspired by the youth, she, her grandchildren and a group of women leaders set up the Sacred Stones Camp on Allard's land as a center for cultural preservation and spiritual resistance (Brígido-Corachán, 2017, p. 72). They said that they were not "protesting" but reclaiming the land that had been stolen from them in violation of the 1851 Fort Laramie Treaty and following their long-standing obligations to "protect" the water (Allard, 2016). They were thus clearly signaling their autonomy from the U.S. state and extractive capitalist order.

At its height in mid-October, \#StandingRock encompassed three Indigenous-led encampments with over 20,000 people living in modern tents, trailer homes, or teepees. They set up a Council Lodge for the Oceti Sakowin leaders to meet, the first time since the 19th century, and significantly, the youth and two-spirit representatives were included among the traditional chiefs and elders. On October 24, they formally proclaimed their territorial sovereignty: "Today the Oceti Sakowin has enacted eminent domain on DAPL lands, claiming 1851 treaty rights. This is unceded land” (Gilio-Whitaker, 7).

If \#StandingRock stretched back in time to earlier Oceti Sakowin commons, they were also reconfiguring the boundaries of their commons and extending their lively ways into cyberspace. Like many Indigenous communities that had been excluded from the commercial telecommunications grid, they skipped over the broadband era and jumped straight to mobile (Guskin \& Mitchell, 2012). Adapting lessons from Idle No More, whose aims had also been to protect Indigenous treaties and territories from extractivism, and had been initiated by three Indigenous women and one settler accomplice, they synergized their onthe-ground encampments with social media communities and allies working in independent media channels (Estes, 2019; Gilio-Whitaker, 2019; Hearne, 2017).

The social media sites provided a scaled up set of self-governed communications spaces. Breaking their isolation, one of the historic tragedies of earlier commons, and working with accomplices from Black Lives Matter, they imagined the hashtag \#StandingRockisEverywere to show the connections between Indigenous peoples in the U.S. and beyond (Lane, 2018, 
p. 208). Grounded in the land-based mobilization, they used an extensive array of digital media to connect, draw people to the camps, and at the same time jump scales and fire up decentralized support actions across the country, the continent and the globe.

The water protectors posted live streams, first-person accounts, photos, and videos via Twitter, Facebook and other social media from the closest cell phone signal connection, that they named Facebook Hill (Johnson, 2017, p. 162). The creation of on-line community engaged people in other geographic regions around the world in observing, sharing and commenting. Importantly, many were inspired to travel to the camps, including some who had never participated in social justice work before, while others carried out direct actions at their own locale (Johnson, 2017, p. 164).

The long-standing systemic marginalization of Indigenous communities by the dominant media meant that the Standing Rock protectors maintained control over communications without much contest until months into the mobilization. Said Desiree Kane, a Standing Rock media coordinator, "Part of what makes this historic is that one of the weapons we have now is our own cameras and our own internet connections to tell our own narratives and stories without having to bow to traditional media outlets that maybe aren't friendly to the cause" (Johnson, 2017, p. 163). Outside media groups were required to report to the media tent, and no photographs were permitted without consent (Estes, 2019, p. 58).

The media time-line followed what has become the norm for social justice movements since 2011 and the Occupy movement (Kidd, 2015). A small corps of Indigenous and nonIndigenous radical media-makers (Unicorn Riot, Digital Smoke Signals, Indigenous Rising, Renegade Media and the Women's Indigenous Media Group) supported them from the beginning. Then, larger independent media outlets such as Mother Jones, and Democracy Now, and Al Jazeera's AJ+ and Russia Today (RT) began to provide regular coverage, especially after a group of young activists organized a relay race to Washington DC in the summer.

Not until September, when law enforcement and private security working for Energy Transfer attacked the water protectors with pepper spray, water cannons, and rubber bullets, did the dominant commercial and public service media produce much news coverage. The BBC was the first major news outlet to provide any detail; with no reporters on site, the U.S. corporate news outlets often reported information second hand from the police and state authorities (Johnson, 2017, p. 162). However, by that point, the water protectors had over a million active followers on their social media accounts, a powerful force in refuting the narrative provided by the police and then echoed by some of the dominant media.

The significance of these allied cyber commons and their virtual media power was clearly demonstrated at several different moments throughout the autumn months. In October 2016, when the Morton County Sheriff's Department was allegedly monitoring Facebook check-ins to identify water protectors at the site, Facebook supporters were asked to "check-in" in a show of solidarity; over 1.5 million people responded (Kennedy, 2016 in Johnson, 2017, p. 164). Regardless of the effectiveness in curbing the police surveillance, as Deem argues, the mass check-ins reconstituted the virtual and the analog in tandem, providing a disembodied presence that lent visibility to the bodies on the ground in a very particular local place (Deem, 2019, p. 124).

Then, on November 15, 2016, the \#NoDAPL Day of Action drew tens of thousands of demonstrators in three hundred solidarity events in all fifty U.S. states, with 7,000 in 
Washington, D.C., and dozens of other world centers, including London, Paris, Toronto, Auckland, Kyoto, and Marrakesh (Schleeter, 2016 in Johnson, 2017, p. 167). “The physical mobilization of supporters across the country and the world who participated in the \#NoDAPL Day of Action demonstrates the power of social media to elicit direct participation and empower movements in ways that were previously impossible" (Johnson, 2017, p. 167).

\section{Commoners}

\#StandingRock represented a very different composition of commoners in scope and scale than the previous radical commons. First, it was based in national and transnational Indigenous networks. At the center, all seven Oceti Sakowin nations symbolically and materially aided them, despite the fact that members of the Manda Hidatas and Arikara or MHA Nation, whose land is also affected by the pipeline, support oil production, with some working in the oil fields (Brígido-Corachán, 2017, p. 85n6). Every single Native American nation gave their support, as did many senior activists from the American Indian Movement (AIM). In addition, they were supported by 380 Indigenous nations from around the world (Brígido-Corachán 77), many of which have been actively involved in the resistance to extractivism.

Second, the Standing Rock youth drew from earlier movements of Idle No More and Black Lives Matter; they encouraged allies from other anti-racist and anti-colonial collectives, as well as creative cross-racial and transnational mobilizations and mediated forms of representation (Brígido-Corachán, 2017, pp. 78-79). Together with the women elders, they took major steps in recognizing the leadership of women and two-spirited people in camp life and direction.

Third, Standing Rock represented a new relationship with non-Indigenous environmental movements, and other settler-led social and political movements. Previously, many Indigenous mobilizations had been subsumed under the white settler-dominated environmental movement, which had not recognized the critical importance of Indigenous sovereignty, land and rights (Brígido-Corachán, 2017; Gilio-Whitaker, 2019; Steinman, 2019; Wiles, 2017). The Standing Rock Sioux encouraged the participation of non-Indigenous allies and accomplices, but their expectation was that everyone should follow their protocols and norms (Gilio-Whitaker, 2019; Steinman, 2019). These changes in leadership were not without significant tensions and contradictions, which I discuss further below.

Fourth, their marshaling of a hybrid of communications expanded both the scope and scale of their campaign and of the larger Indigenous led extra-activist movement. Two thousand veterans, many of whom were Indigenous, answered the call on social media and showed up to support the water protectors. Musicians and celebrities also participated by creating music videos, some of which attracted millions of viewers on Youtube and other platforms. The \#NoDAPL Day of Action on November 15, 2016, a decentralized event largely organized via social media, demonstrated the connection among locally organized groups across the U.S. and the planet. Since then, several Indigenous-led land-based struggles against extractivism have drawn on the Standing Rock media power and called themselves 'the next Standing Rock" (Saunders, 2018; Wiles, 2017). 


\section{Commoning}

The efforts of the Standing Rock Sioux to stop the Dakota Access Pipeline featured a range of strategies from legal actions and political lobbying at the local courthouse, state capital and in Washington; two cross-country relay runs; direct and active resistance to the construction of the pipeline; and extensive decolonizing media activist practices (BrígidoCorachán, 2017; Cappelli, 2018). The three encampments provided the hub for many of the above practices. Regular assemblies included everyone in collective reflection and decisionmaking (Brígido-Corachán, 2017, p. 76). The collective living spaces provided opportunities for multiple informal encounters that nurtured relations of mutuality with fellow commoners, allowed for conversation and for envisioning alternative ways of organizing society. (Sharma \& Wright, 2009 in Fortier, 2017).

Nick Estes (2019) describes the ethos of intergenerational care giving and generosity in the daily collective practices in the main camp as befitting a "fully functioning city" (58). Under the direction of the Standing Rock Sioux elders, a steady rotation of young Indigenous men kept the fires going, several free camp kitchens provided three meals a day, and a donations tent equipped everyone with clothes, tents and essentials to keep everyone warm, an essential service during the winter cold (Estes, 2019, pp. 58-59). TwoSpirit activists led some of the prayers and marches, and participated in the camp council, in the school, in security, food preparation and as medics (61-62).

The commoning practices at Standing Rock reasserted traditional Sioux practices. Key among these was "prayer." Every morning in the Sacred Stone camp, the water protectors prayed, fed the sacred fire, and shared their food with their ancestors. The ground rules and action principles were posted throughout the camps, saying: "Water is sacred"; "We are peaceful and prayerful”, "This is a ceremony, act accordingly" (Brígido-Corachán, 2017). Reasserting these traditional practices strengthened kinship relations and brought Oceti Sakowin youth closer to traditional Lakota and Dakota culture (Brígido-Corachán, 2017, p. 76). Embracing non-human beings and formations such as the water and earth, they changed the language and practice of contention off and on-line. The hashtag \#mniwiconi (water is life) embodies the understanding that water is a material resource which is essential for health, wellness, irrigation, and human survival, and amplified their message and identification as water protectors, not protesters, again emphasizing caring and solidarity, not conflict.

Anti-colonial education was also a key dimension of recovering their knowledge commons after centuries of erasure. A fully functioning day school was facilitated by "an unprecedented concentration of Indigenous knowledge keepers" with an anticolonial curriculum about Indigenous treaties, language, song, dance, math, history, nonviolent direct action and water defense (Estes, 2019, p. 60). Some of the younger Indigenous women linked the local oil boom to the corruption of tribal councils and the subsequent increase of drug use, sex trafficking, and sexual violence and they focused their work on teaching and healing with youth against the ravages of alcoholism, suicide, and abuse (Brígido-Corachán, 2017, p. 78).

The media collectives such as Indigenous Rising and Indigenous Rising Media set important examples of decolonizing media representation, "reshap[ing] the Indigenous subject in the national and global imaginary" and representing a radical form of visual sovereignty (Brígido-Corachán, 2017, p. 80). Indigenous Rising Media emphasized 
community, land-based activity, creativity, and everyday resistance in their portrayal of camp life. They created new visual formats for digital channels that challenged Western narratives, deliberately avoiding colonialist tropes of vast and uninhabited landscapes and warriors on horseback, and instead recombining older historical imaginaries with contemporary media esthetics (70-71). For example, Indigenous Rising Media created several Facebook albums that traced their connection to their anti-colonial era resistance, one of which honors Brenda White Bull, the granddaughter of Sitting Bull, who last brought the Sioux tribes together against the U.S. government at the end of the 19th century (82).

The Standing Rock encampments were far from conflict-free. There was, as one might expect, a continuing tension over tactics in the encampments. Some participants challenged the tribal leadership (Steinman, 2019) and carried out more direct actions such as blocking the construction machinery. There were also tensions over gender roles and dress; the elders' dress protocol for ceremony included full-length skirts, and they expected all women to comply. By the fall, women in pants were encouraged to wear full-length skirts (Johnson \& Kraft, 2017). The virtual commons also reflected major differences in political strategies as many of the participants operated within a discourse of climate change and environmental accountability separated from Indigenous rights and perspectives (Deem, 2019, p. 125).

\section{Discussion}

The Standing Rock encampments provided the space and time for people to grow new collective imaginaries and develop narratives to spread them. At Standing Rock, participants constructed these new collective imaginaries through a complex process that combined group education and critique about the resource industries plans and the U.S. government's role in enclosing and displacing the Oceti Sakowin; and at the same time their own historical memories of iconic leaders and collective resistance, and of how to live together in their own territories. The hybrid networks of on/offline communicative spaces allowed, as communications scholar Merlyna Lim (2018) has written, for a collective imaginary about Indigenous history and environmental knowledge and governance to emerge from a process that was both cognitive and corporeal; and which involved a specific political focus (108) as well as more everyday concerns (108).

The Standing Rock encampments were ultimately disbanded in early 2017 and the pipeline completed. Nevertheless their mobilization has rippled across the continent and beyond. In the ensuing years, several European banks financing DAPL have sold their shares and have abandoned further projects with Energy Transfer as a result of the connection made with Sami performers at the Sacred Fire of Oceti Sakowin (Johnson \& Kraft, 2017). In March 2020, the Standing Rock Sioux won a significant victory when a federal court judge ordered the U.S. Army Corps of Engineers to conduct an extensive environmental review of the pipeline, with a further decision about a temporary shut- down until the review is completed expected sometime later in 2020 (Friedman, 2020). Several other Indigenous-led land-based struggles against extractivism across the U.S. and Canada, in Norway and eastern India, have invoked the Standing Rock media power (Saunders, 2018; Wiles, 2017).

Much more needs to be elaborated on the Indigenous commons and on the lessons for other radical communications commons. Not all commons, it is important to note, are worth defending, nor do all commoning processes necessarily result in an "alternative" 
commoner (Velicu \& García-López, 2018, p. 6). In a context of power inequalities, we cannot assume that more (face-to-face) communication necessarily leads to cooperation; indeed it may contribute to increasing aggression (5). New enclaves of "community" can become new sites of enclosure, with potential violence in individualist, nationalist, patriarchal or racist overtones (Caffentzis \& Federici, 2014). There is thus a need to consider the historical and contemporary particularity of each commons, the systems of governance that are always in the making, as well as the contradictions and fluidity of identities among commoners (Linebaugh, 2008; Velicu \& García-López, 2018).

Standing Rock begs for several correctives to the radical commons framework. First, the Standing Rock Sioux water protectors were not protesters coming anew to private or public land, but were reestablishing collective sovereignty on territories that had been violently taken from them. Their commoning practices were based in re-encoding legacy knowledges and protocols that had been systemically invisibilized. As Fortier argued (2017), this behooves us and future tactical commons organizers to challenge the settler notion of rural and urban space as terra nullius, or empty of Indigenous sovereign presence, and instead learn from and take direction from Indigenous peoples in their territories. In extension, this also means always carefully considering the residual movements wherever new commons are formed.

Secondly, Standing Rock challenged some of the simplistic ideas of horizontalism in which egalitarian leadership is said, as with the Occupy movement, to develop ad hoc, in situ and open to all. At Standing Rock, supporters from other Indigenous and nonIndigenous nations were welcome to participate, on the condition that they recognized Standing Rock leadership and followed camp rules (Gilio-Whitaker, 2019). In addition there was a recognition of women and LGBTQ people, who were centrally involved as part of the leadership of day-to-day routines and within the Oceti Sakowin council (Estes, 2019; Gilio-Whitaker, 2019). In future commons, one of the first steps will need to be to formulate governance structures that acknowledge power differences and support an intersectional shift in power relations.

Thirdly, Standing Rock highlighted Indigenous practices of reciprocity with nature and all sentient beings. They challenged colonial, anthropomorphic, gendered and racialized knowledges and behaviors; and instead collectively built qualitatively different social relations in generative practices which emphasized cooperation and responsibility to each other and to the water, earth, forests, animals and the sea (Federici, Velicu \& García-López, 2018). The future to which both Estes (2019) and Coulthard (2014) point, is a more complete ecological perspective about human and non-human relations and the necessary protocols to survive.

\section{Notes}

1. The river's Lakota name is Inyan Wakangapi Wakpa or "river that makes the Sacred Stones." This area was home to historically important burial grounds, sacred sites and trading places of the Standing Rock Sioux, the Arikara, the Mandan and the Northern Cheyenne (BrígidoCorachán, 2017, p. 72).

2. This includes the Mi'kmaq Blockade and Elsipogtog (Howe, 2015) on the Atlantic coast of Canada and campaigns against Line 9 in Ontario ) Line 3 in Minnesota, as well as campaigns of the Lummi in Washington State, the Houma in Louisiana, the Navajo, Tohono O'Oodham, the Yaqui and Apache in New Mexico and in Arizona (Brígido-Corachán, 2017), and the current 
anti-pipeline struggles of the Secwepémc and Wet'suwet'en in British Columbia, Canada. It also includes similar anti-extractivism movements of the Sami in Norway.

3. Inspired by them, I began a longer research project about the communications practices of extra-activist movements. First, I reviewed the historical and current extra-activist struggles, and conducted a content analysis of dominant news representations of extra-activist struggles (Kidd, 2014a, 2014b, 2016). Secondly, I conducted case studies of communications practices used by extra-activist movements in Latin America and Canada (videos (Kidd, forthcoming); and counter-mapping (Kidd, 2019).

\section{Disclosure statement}

No potential conflict of interest was reported by the author.

\section{Notes on contributor}

Dorothy Kidd teaches media studies at the University of San Francisco. One of her principal research projects is the documentation of communications practices by anti-extractivist movements.

\section{References}

Allard, L. D. (2016, November 2). Why do we punish Dakota pipeline protesters but exonerate the Bundys? The Guardian. Retrieved from https://www.theguardian.com/commentisfree/2016/nov/ 02/dakota-pipeline-protest-bundy-militia

Blomley, N. (2008). Enclosure, common right and the property of the poor. Social \& Legal Studies, 17 (3), 311-331. doi:10.1177/0964663908093966

Brígido-Corachán, A. (2017). Material nature, visual sovereignty, and water rights: Unpacking the standing rock movement. Studies in the Literary Imagination, 50(1), 69-90. doi:10.1353/ sli.2017.0006

Caffentzis, G., \& Federici, S. (2014). Commons against and beyond capitalism. Community Development Journal, 49(suppl 1), 92-105. doi:10.1093/cdj/bsu006

Cappelli, M. L. (2018, July-September). Standing with standing rock: Affective alignment and artful resistance at the native nations rise march. SAGE Open, 1-13.

Coulthard, G. (2014). Red skins, white masks: Rejecting the colonial politics of recognition. Minneapolis: University of Minnesota Press.

de Angelis, M. (2014). Social revolution and the commons. The South Atlantic Quarterly, 113(2), 299-311. doi:10.1215/00382876-2643630

Deem, A. (2019). Mediated intersections of environmental and decolonial politics in the No Dakota access pipeline movement. Theory, Culture \& Society, 36(5), 113-131. doi:10.1177/ 0263276418807002

Deleixhe, M. (2018). Conflicts in common(s)? Radical democracy and the governance of the commons. Thesis Eleven, 144(1), 59-79. doi:10.1177/0725513618756089

Epstein, A. (2015, January 13). The colonialism of the present: An interview with Glen Coulthard. Jacobin. Retrieved from https://www.jacobinmag.com/2015/01/indigenous-left-glen-coulthardinterview/

Estes, N. (2016, September 18). Fighting for our lives: \#NoDAPL in historical context. The Red Nation. Retrieved from https://therednation.org/2016/09/18/fighting-for-our-lives-nodapl-incontext/

Estes, N. (2019). Our history is the future: Standing Rock and the Dakota access pipeline, and the long tradition of indigenous resistance. New York, NY: Verso Books.

Federici, S. (2019). Re-enchanting the world: Feminism and the politics of the commons. Brooklyn, N. Y.: Autonomedia. 
Fortier, C. (2017). Unsettling the commons: Social movements within, against, and beyond settler colonialism. Winnipeg, Man: Arbeiter Ring.

Friedman, L. (2020, March 25). Standing Rock Sioux tribe wins a victory in Dakota access pipeline case. New York Times. Retrieved from https://www.nytimes.com/2020/03/25/climate/dakotaaccess-pipeline-sioux.html

García López, G., Velicu, I., \& D’Alisa, G. (2017). Performing counter-hegemonic common(s) senses: Rearticulating democracy, community and forests in Puerto Rico. Capitalism, Nature, Socialism, 28(3), 88-107. doi:10.1080/10455752.2017.1321026

Gilio-Whitaker, D. (2019). As Long as Grass Grows: The Indigenous Fight for Environmental Justice, from Colonization to Standing Rock. Boston, Mass: Beacon Press.

Guskin, E., \& Mitchell, A. 2012. Innovating news in native communities. In the state of the news media, 2012. Pew Research Center Project for Excellence in Journalism. Retrieved from http://www. stateofthemedia.org/2012/native-american-news-media/

Hardison, P. (2006, November 20). Indigenous peoples and the commons. On the commons. Retrieved from http://www.onthecommons.org/indigenous-peoples-and-commons\#sthash. rKeRo2et.dpbs.

Hearne, J. (2017). Native to the Device: Thoughts on Digital Indigenous Studies. Studies in American Indian Literatures, 29(1), 3-26.

Hollender, R. (2016). A politics of the commons or commoning the political? Distinct possibilities for post capitalist transformation. Spectra, 5(1), 1-15. doi:10.21061/spectra.v5i1.351

Howe, M. (2015). Debreifing elsipogtog: The anatomy of a struggle. Halifax, Canada: Fernwood Publishing.

Johnson, G., \& Kraft, S. (2017). Standing on the sacred: Ceremony, discourse, and resistance in the fight against the black snake. Journal for the Study of Religion, Nature and Culture, 11(1), 131-147. doi:10.1558/jsrnc.32617

Johnson, H. (2017). \#NoDAPL: Social media, empowerment, and civic participation at standing rock. Library Trends, 66(2), 155--175.

Kanngeiser, A., \& Beuret, N. (2017, April). Refusing the world: Silence, commoning and the anthropocene. The South Atlantic Quarterly, 116(2), 363-380. doi:10.1215/00382876-3829456

Kennedy, M. (2016). More than 1 million 'check in' on facebook to support the standing rock sioux. Two-Way (blog), National Public Radio. http://www.npr.org/sections/thetwo-way/2016/11/01/ 500268879/more-than-a-million-check-in-on-facebook-to-support-the-standing-rock-sioux.

Kidd, D. (1998). Talking the Walk: The Communications Commons Amidst the Media Enclosures (Unpublished doctoral dissertation). Simon Fraser University.

Kidd, D. (2014a). We can live without gold but not without water. In A. L. Roth \& M. Huff (Eds.), Project Censored 2014 (pp. 223-243). Oakland. CA: PM Press.

Kidd, D., with Fugazzola, C. (2014b). Dreaming Joe Hill: Insurgent communications in contests over our common resources. In D. Leadbeater (Ed.), Resources, empire and labour: Globalization crises and alternatives (pp. 304-318). Black Point, Canada: Fernwood Publishing.

Kidd, D. (2015). Occupy media: Media democracy and participatory communication. In C. Atton (Ed.), The companion to alternative and community media (pp. 457-468). New York, NY: Routledge.

Kidd, D. (2016). Extra-activism. Peace Review, 28(1), 1-9. doi:10.1080/10402659.2016.1130365

Kidd, D. (2019). Challenging knowledge-making in the extractive zone. Information, Communication \& Society, 22(7), 954-970. doi:10.1080/1369118X.2019.1581243

Kidd, D. (forthcoming). Mobilizing with video in the extractive zone. In C. Robé \& S. Charbonneau (Eds.), InsUrgent media from the front: A media activism reader. Bloomington: Indiana University Press, 151-173.

Klein, N. (2014). This changes everything: Capitalism vs. the climate. New York, NY: Simon \& Schuster.

Lane. T.M. (2018). The frontline of refusal: Indigenous women warriors of standing rock. International Journal of Qualitative Studies in Education, 31(3), 197--214.

Lennard, N. (2017, September 19) Still fighting at standing rock. Esquire. Retrieved from https://www. esquire.com/news-politics/a12181154/still-fighting-at-standing-rock/ 
Lim. M.R. (2018). Routes, and routers: Communications and media of contemporary social movements. Journalism \& Communication Monographs, 20(2) 92-136.

Linebaugh, P. (2008). The Magna Carta Manifesto: Liberties and commons for all. Berkeley: University of California Press.

Linebaugh, P. (2010, January 8). Some principles of the commons. Counterpunch.

Menzies, C. (2010). Indigenous nations and marxism: Notes on an ambivalent relationship. New Proposals: Journal of Marxism and Interdisciplinary Inquiry, 3(3), 5-6.

Montano, J. P. (2011, September 24). An open letter to the occupy wall street activists. Retrieved from https://mzzainal-straten.blogspot.com/2011/09/open-letter-to-occupy-wall-street.html

Petronzio, M. (2016, December 7). How young Native Americans built and sustained the \#NoDAPL movement. Mashable. Retrieved from https://www.mashable.com/2016/12/07/standing-rocknodapl-youth/\#FYOoczmbpqq5

Rueck, D. (2014, September). Commons, enclosure, and resistance in Kahnawa: KeMohawk Territory,1850-1900. The Canadian Historical Review, 95(3), 352-381. doi:10.3138/chr.2556

Saunders, S. (2018, July 5). Personal interview with Author.

Schleeter, R. (2016). \#NoDAPL day of action draws tens of thousands, lights up social media. Greenpeace. http://www.greenpeace.org/usa/nodapl-day-action-draws-tens-thousands-lightssocial-media/.

Singh, N. (2017). Becoming a commoner: The commons as sites for affective socio-nature encounters and co-becomings. Ephemera: Theory and Politics in Organization, 17(4), 751-776.

Steinman, E. (2019). Why was Standing Rock and the \#NoDAPL campaign so historic? Factors affecting American Indian participation in social movement collaborations and coalitions. Ethnic and Racial Studies, 42(7), 1070--1090.

Turner, T., \& Brownhill, L. (2004). We want our land back: Gendered class analysis, the second contradiction of capitalism and social movement theory. Capitalism, Nature, Socialism, 15(4), 21-40. doi:10.1080/1045575042000287307

Velicu, I., \& García-López, G. (2018). Thinking the commons through Ostrom and Butler: Boundedness and vulnerability. Theory, Culture \& Society, 1-19.

Walker, J., \& Walter, P. (2018). Learning about social movements through news media: Deconstructing New York Times and Fox News representations of standing rock. International Journal of Lifelong Education, 37(4), 401-418. doi:10.1080/02601370.2018.1485184

Waziyatawin. (2014, November 14). Speaks to occupy Oakland. Youtube. Retrieved from https:// www.youtube.com/watch?time_continue $=50 \& v=$ naY3VFdTKEc\&feature $=$ emb_logo

Whyte, K. (2017). The Dakota access pipeline, environmental injustice, and U.S. Colonialism. Red Ink, 1(9), 154-169.

Wiles, T. (2017, January 23). Standing Rock's ripple effects. High Country News, 49(1), 14-19. 